\title{
Regina Mundi: Serving the liberation movement in South Africa
}

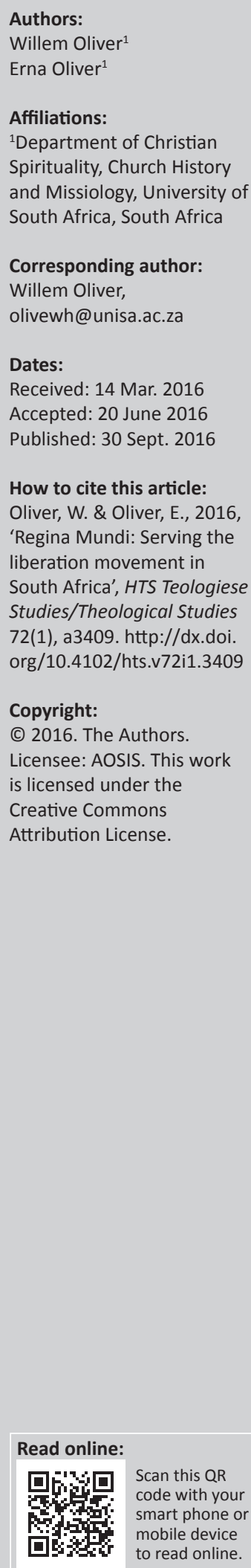

\begin{abstract}
The struggle for 'non-white' South Africans to eventually become liberated in this country was a very tough and bloody one. In the struggle the South African Native National Congress later renamed to African National Congress - as a liberation movement played a decisive role from the beginning of the 20th century, as the mainstream churches failed in the previous three centuries to really contribute to the liberation process. However, the Regina Mundi Catholic Church in Soweto serves as a good example of a church that did not look the other way during the struggle. This church assisted the liberation movement in promoting freedom for everyone, serving as the platform for many a politician and even, at least once, as a shelter against the raining bullets of the police.
\end{abstract}

\section{Introduction}

In 1987, Zolile Mbali wrote a book called The Churches and Racism: A Black South African Perspective in which he stated the following grievous words:

I write this book for my fellow South Africans, remembering especially those who are unable to write or publish a book in their situation, but whose lives are 'living testimonies'. Times are bad now, and they often are for us black people. But we will go on speaking, writing, thinking and acting for our freedom. One day, soon, we shall be free. In the meantime we continue by many different ways in our struggle. (Mbali 1987:inner page)

This book was written while Nelson Mandela was still serving a lifelong sentence of imprisonment on Robben Island. It was written during the 'bad times' when South Africa was encapsulated in a civil war for the freedom of 'non-whites'. This article deals with that struggle for liberation, especially the struggle after the formation of the South African Native National Congress (SANNC) in 1912, focussing on the events taking place on 16 June 1976, in which one church, Regina Mundi, played a significant role in protecting the children of the nation against the police. A comprehensive discussion on Regina Mundi is presented, compiled from a vast array of snippets on this church. Not much literature is available on this monumental church, and therefore the aim of this article is to make more people in South Africa aware of Regina Mundi as well as to supply as much information as possible on the church.

\section{The role of the churches in the struggle before the 20th century}

In the abstract, mention is made of the mainstream churches who failed in the previous three centuries to really contribute to the liberation process. It is not the aim of this article to involve itself with the debate about the contribution or the lack of it, from especially the mainstream (English) churches during the 18th and 19th centuries, with the liberation struggle of the Black, mixed-race and Indian people in South Africa. It suffices to mention that the English-speaking mainstream churches (the Anglican Church, the Catholic Church, Presbyterian, Congregational, Methodist and Reformed Presbyterian churches, the SACC [South African Council of Churches] and the evangelical Church of England) appeared before the Truth and Reconciliation Commission (TRC) during November 1997 'to apologise to black congregants for failing to do more to challenge the former government's discriminatory policies' (South African Press Association 1997). At least (most of) the English-speaking churches tried to do something during these centuries, while (most of) the Afrikaans-speaking churches were supporting the government who oppressed the Black people with apartheid laws, specifically from 1910 and more so after 1948 when the National Party came into power in the Union of South Africa, and continued ruling after South Africa became a Republic in 1961. The Afrikaans-speaking (reformed) churches are up to this very day in practice still not fully open to all members of the community. 
However, having said that, there was one church that, from its foundation in 1961, did not turn a blind eye to the struggle but, against the laws of the time, accommodated secret meetings of the liberation forces, and that was Regina Mundi in Soweto (Figure 1).

\section{Short overview of the period before 1961: A period of non-violent struggle}

This subheading serves as a cursory introduction to the next subheading where the foundation and involvement of Regina Mundi will be discussed. Pixley ka Isaka Seme has founded the SANNC in Bloemfontein on 8 January 1912 as a resistance movement against the apartheid regime (SAHO s.a.). John Langalibalele Dube became the first President of this organisation (Rakolote 2013). Oliver Tambo depicted the reason for the formation of the African National Congress (ANC) in the following words: 'It was to terminate the violence against our people, which is inherent in White minority domination, that the ANC was formed' (ANC 1992). Seme also founded a newspaper to act as the mouthpiece of the movement. D.S. Letanka of Morumioa ('The Messenger') a paper mainly distributed among the Tshwana and the Pedi in the northern parts of the then Transvaal - agreed to merge his newspaper with the proposed movement (Switzer 1997:30). The newly founded paper's name was Abantu-Batho with C. Kunene as English and Zulu editor and Letanka as Sotho editor (Thema 1953).

It is important to note that the SANNC was formed without having an armed struggle in mind (Oliver Tambo ANC 1987). The SANNC became the ANC in 1923 under the leadership of Sefako Makgato. Just after the Sharpeville massacres in March 1960, the ANC was banned as a political movement by the government. At least two other resistance movements were also active and banned in South Africa, namely the South African Communist Party (SACP) (cf The History of the SACP 1912-1990 s.a.) and the Pan Africanist Congress (PAC) (cf The Associated Press 1960).

\section{1-1976: Regina Mundi became part of the armed struggle for liberation}

Nineteen sixty one was a very important year in the history of South Africa for more than one reason:

- The Republic of South Africa was founded on 31 May 1961, introducing a period of approximately 30 years of harsh apartheid enforcement.

- This marked the year in which the ANC decided to start with the armed struggle against the nationalist government, with the formation of MK (Umkhonto we Sizwe - meaning 'spear of the nation') to 'hit back by all means within our power in defence of our people, our future and our freedom' (ANC 2011). Nelson Mandela was the first leader of the organisation. Oliver Tambo justified this action by saying that the apartheid regime left the ANC no choice but to take up arms (ANC 1987).

- It also marked the year in which the Catholic Church in Soweto, named Regina Mundi, was founded.

With the Sharpeville massacres still fresh in the mind of the people of South Africa, Father Gerard Coleman and his building team started to build a church in 1961 (during the

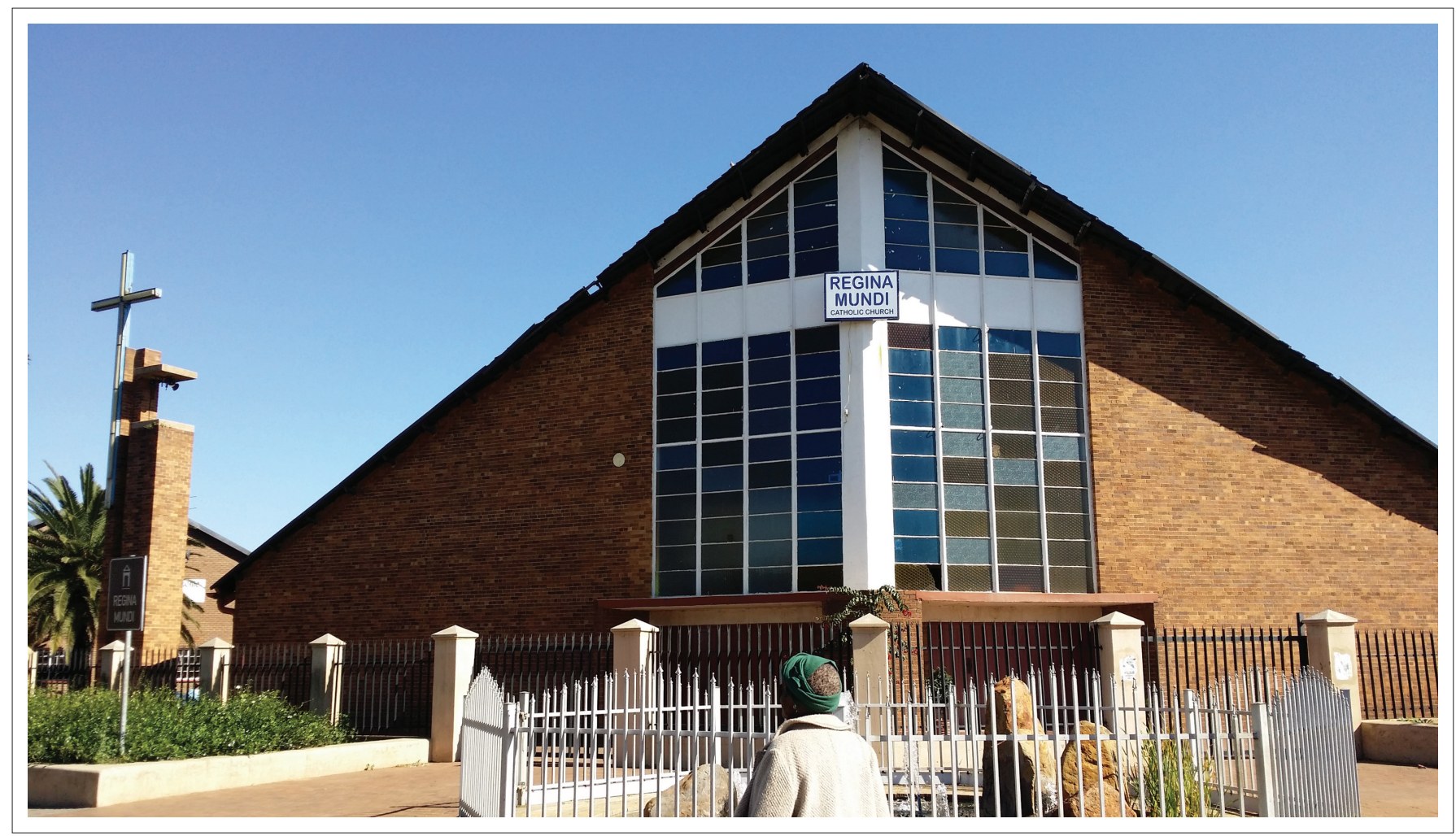

Source: Authors' own work

FIGURE 1: Regina Mundi Catholic Church and the struggle for liberation. 
time of forced removals) in the middle of Soweto, in Moroka (Rockville), in the most populous Black urban residential area in the country (Garson 2004). Moroka was named after the eighth President of the ANC, Dr James Sebe Moroka. It was later given the nickname Rockville because of all the large rocks being unearthed while the people dug the soil (Ndlovu et al. 2012:21). Cardinal Johannes Baptista Montini from Milan came to South Africa and blessed the foundation of the church on 24 July 1962. The Regina Mundi Church is the largest Roman Catholic Church in South Africa (Hlangani 2012). Although the A-shaped exterior of the building is a quite ordinary design, the vast interior of the church can seat 2000 congregants, while providing standing room for another 5000. The Latin Reginae Mundi refers to the virgin Mary and can be translated with 'Queen of the World'. It was officially opened on 15 August 1964 by Father Coleman (Ndlovu et al. 2012:29).

This church became renowned as it first wrote its name in the history books of South Africa during the apartheid era, when it opened its doors to anti-apartheid groups and provided shelter to activists. In 1964, just after the church had been taken into use, Nelson Mandela, Walter Sisulu and other ANC leaders were sentenced to life imprisonment on Robben Island following the Rivonia Trial. As the ANC was a banned organisation, they had to organise everything in secret. Regina Mundi was just the right place to gather. Quite soon this church became the spiritual centre of the resistance movement, being called by Nthato Motlana 'not just a church - it is the people's church, the church of the nation' (cf Garson 2004). The 1995 version of the Kairos Document referred to the church as follows:

A church of the people, a home and a voice in the struggle. A place of suffering, protest, and celebration. A sanctuary where the living were encountered, where our hope for liberation was enkindled, and where the spiritual quest for justice and peace was sustained. (Kairos Document 1995)

As an 'interlude', it serves to mention here that in 1969 the ANC held a conference at Morogoro in Tanzania. They decided that they needed both an armed struggle and a mass political struggle to make an impact on the government in South Africa. They also began to look for international help in the form of finances. At this conference, they started with the four famous pillars of the struggle, namely Fight, Mobilise, Produce and Learn (ANC Archives s.a.).

In 1974 Regina Mundi was 'officially' named a 'political church' or a church 'taken over by Communists' as it became the 'centre of black political activities' (Ndlovu et al. 2012:78). This was also the year in which W.C. Ackerman, the regional director of Bantu Education in the Southern Transvaal, under the rule of the Minister of Bantu Education, M.C. Botha, declared that school children in Forms 1 and 2 (the first 2 years in Junior Secondary School) would have to learn mathematics, geography, physical science and biology in Afrikaans. During 1975, all the Black junior secondary schools were learning in English. In the same year, the Department of Bantu Education decided to move to Standard 6 (now Grade
8) from the primary school to the junior secondary schools as from 1976. Almost 260000 children wanted to enrol for Standard 6 that year, while there was only space for approximately 40 000. There was chaos. Education became the time bomb, and Soweto was in the midst of it all.

\section{June 1976}

In 1976, the Department of Bantu Education enforced Afrikaans as a medium of education in selected schools on a 50-50 basis (higher primary and junior secondary schools - from Standard 5 (now Grade 7) onwards mathematics and social studies would be taught in Afrikaans, with general science and practical subjects to be taught in English (Davie 2006) therefore forcing the children who advanced to secondary school to adapt to two 'foreign' languages in 2 years' time (Ndlovu 2006:327). According to Mashabela (2006:18-19) 'Soweto was shaken'.

When the schools opened in January 1976, parents and principals were unhappy about the situation (Davie 2006). During March 1976, school children formed their own meetings and implemented slowdowns and class boycotts (Simbao 2007:52). Come June 1976, Forms 1 and 2 children at Orlando West Junior Secondary School in Soweto started to boycott their classes (Boddy-Evans 2001:Part 2). Seven schools in their vicinity joined in. The special branch of the police arrived and talked to the principal of the school. This caused the children to go out and overturn the police vehicles (Boddy-Evans 2001:Part 2).

On 13 June, a meeting was held in Orlando, addressed by 19-year-old youth leader Tsietsi Mashinini, where he suggested that the school children must have a mass demonstration against the use of Afrikaans as the medium of instruction in their schools on the following Wednesday, 16 June 1976. Four hundred children attended the meeting. This led to the children taking to the streets of Soweto on 16 June that year. Two things contributed to this riot (Wilkins \& Strydom 2012:217):

- Not long ago, Portugal withdrew from Mozambique and Angola, handing these countries over to the 'black guerrilla movements'.

- The youth had the conviction that their elders did not have the drive to fight for liberation as they were 'intimidated by the white man'.

Between 10000 and 15000 children (between the ages of 10 and 20) made their way to Orlando West Secondary School in Vilakazi Street and marched the streets singing Senzeni na? (What have we done?) They were peacefully marching to Orlando Stadium (Davie 2006; Ndlovu et al. 2012:80 said they were marching to the New Canada Education Department), carrying placards with slogans such as 'Away with Afrikaans', 'We are not educated but certificated', 'Afrikaans must be abolished' and 'We are fed by the crumbs of education'. Their plan was to go to the stadium and to hand over a memorandum containing a list of their grievances to the offices of the 
Transvaal Department of Education in Booysens in south Johannesburg (Davie 2006; Ndou 2014:2).

Before the children even reached the stadium, the police met them in Orlando West and gave them 3 minutes to disperse, which the children ignored. The police then fired tear gas into the crowd and released police dogs. The children began to run while throwing stones and bottles at the police. Suddenly one of the policemen took out his revolver and shot directly at the children (Boddy-Evans 2001:Part 2). This triggered the policemen present to draw their firearms and to shoot at the children. Hector Pieterson (also spelled Peterson, Petersen and Pietersen), a 12-year-old pupil from Thesele Higher Primary School, with the nickname Chopper (Hlongwane, Ndlovu \& Mutloatse 2006:89) was the first to get shot and he was fatally wounded. The police reported that he was hit by a stray bullet on the corner of Moema and Vilikazi streets (Simbao 2007:53), while a post-mortem indicated that he was 'killed by a shot fired directly into him' (Boddy-Evans 2001:Part 2). Mbuyisa Makhubu (who mysteriously disappeared and was much later found in a Canadian jail in 2013 [Komane 2013; also cf Keung 2014]) picked him up to take him to the Phefeni Clinic, with his distraught half-sister, Antoinette Sithole, walking with them. Samuel Nzima, who was a photojournalist for The World, took a photo of this incident. (According to Nzima, now over 80 years old, he lost his job as he was threatened by the 'apartheid government' because of that photo - Ndou 2014:2) Davie (2006) reported:

Then all hell broke loose. Students targeted apartheid symbols: administrative offices, government buses and vehicles and municipal beer halls, which were first looted and then set alight. By the end of the day thick clouds of black smoke hung over the township, and the streets were littered with upturned vehicles, stones and rocks. Anti-riot vehicles poured into Soweto, roadblocks were erected at all entrances, the army was placed on alert and helicopters hovered overhead, dropping teargas canisters and shooting ... As night fell, the unlit township became even more terrifying: blinded by the night, police simply fired into the blackness. The students returned the fire with their own weapons: bottles and stones. The looted liquor was taking effect - people wandered the streets intoxicated, in a celebratory mood, raising clenched fists and shouting 'Amandla!' (power). (p.)

While it was reported that only 23 children died that day, other reports estimated the body count on close to 200 (Boddy-Evans 2001:Part 2). Phefeni Clinic and Baragwanath Hospital were filled with 'youth perforated with gunshot wounds' (Simbao 2007:53). There were also three white people who lost their lives in Soweto that day, of whom Dr Melville Edelstein - a social welfare worker under the black people in the township - was one who was stoned to death at the Morris Isaacson High School (Wilkins \& Strydom 2012:216, 225). The uprising went on the next day, spreading to another township, Alexandra, and from there to the East and West Rand, northern Natal and Cape Town (Wilkins \& Strydom 2012:216), resulting, by the end of the year, in more than 1000 children being killed (Wilkins \& Strydom [2012:216] noted that it was 499), mostly by the police, almost 4000 injured, and almost 6000 arrested by the police (Davie 2006).
Regina Mundi gained prominence in the 1976 uprising when it refused to close its doors for services and political gatherings and when it gave shelter to activists running away from the police. Especially on 16 June 1976 with the school children's uprisings, many of these protesting children who were on their way to Orlando Stadium fled from west Orlando West to the church for sanctuary to escape the bullets and tear gas canisters of the police. Inside the church the children were assisted with buckets full of water to help them recover from the tear gas. Although the children thought that they would be safe inside the church, the police followed them into the church and fired live ammunition at them. Hlangani (2012) reported:

No one was killed [inside the church - my addition], although many were injured and the church itself, as well as its furniture, decorations, and symbols (for example the marble altar and the statue of Christ), were damaged. Both the interior and the external walls of the church still bear the signs of the shootings. (n.p.)

Even today bullet holes are visible in the church's ceiling and damaged marble altar. Funerals of the people killed by the police were held at this church and buried at Avalon Cemetery.

This was one of the defining moments in the history of South Africaa turning point in South Africa's history, the beginning of the end of apartheid (Ndlovu 1998:1). The photo taken by Nzima of the dying Hector Pieterson was also depicted as a 'turning point in South Africa's history' as it was 'circulated worldwide and for the first time many began to realise how evil apartheid was' (Ndou 2014:2).

These events would invigorate the ANC, the PAC and Black Consciousness Movement (BCM) to actively stand up in the struggle against apartheid. Ndlovu et al. (2012) elaborated on this:

The youth became uncontrollable. Student organisations were banned, one after another by the apartheid regime and many fled into exile. The townships became ungovernable. Communities joined the resistance by refusing to pay for electricity and rent. Suspected informers were harassed or 'necklaced'. The homes of police and local council members were set alight and delivery vans, buses and trains were torched. (p. 10)

In Soweto, South Africa Student Movement (SASM) was formed by secondary school children and was one of the first organisations of its kind in South Africa. The underground ANC linked the struggle of the children with their own struggle for national liberation.

Since that day, every year on 16 June, people gathered at Regina Mundi, as the church 'became a shrine of resistance by default' (Ndlovu et al. 2012:10). There was, however, no unity between the liberation fighters:

The yearly June 16 commemoration services were held along partisan lines. If you believed in the ANC's Freedom Charter you attended a UDF service; if you swore by the $\mathrm{BCM}$ and the Azanian Manifesto you went to an AZAPO rally. And, if you were Pan Africanist, as espoused by Robert Sobukwe, you 
attended services organised by the internal organs of the PAC. (Hlongwane 2008:151)

\section{Regina Mundi in constant service of the people of the land}

The meetings of the oppressed did not stop but gained new momentum. Numerous meetings were held at Regina Mundi. Virtually all these meetings were ended by police who drove the participants away with tear gas and sjamboks. Tear gas became the 'incense of the day' (Ndlovu et al. 2012:10). On 27 February 1978, Robert Sobukwe, the leader of the PAC, died. His memorial service was held in this church for a full week during the evenings (Ndlovu et al. 2012:87). Political meetings in South Africa were banned in most public places during the 1980s. This church, however, was a place where the people of Soweto could meet and discuss during the anti-apartheid struggle, as it 'quietly' offered protection to those who struggled for liberation (Garson 2004). Sometimes a church service and even a funeral ended up in a political meeting (Garson 2004; Hlangani 2012). Both Don Mattera (a poet and author) and political activist Ishmael Mkhabela recounted that they used the church for the purpose of political meetings and rallies (Xaba 2012). In a personal interview with Sinda Msimang (on 24 April 2014 at the church), a member of Regina Mundi from its foundation, he recalled the political meetings held at the church. According to him, the police showed up at most of the political meetings at the church, dispersing the attendees with whips and sjamboks, and when they were outside, they were met with tear gas. (He was still too emotional to relate the events of 1976.) This is the reason why Regina Mundi was one of the main centres of anti-apartheid activism and why the people often referred to this church as 'the people's church' or 'the people's cathedral'.

This went on till the late 1980s when the church decided not to be the site of commemorations any longer (Ndlovu et al. 2012:86). In 1989 (eight months before political organisations were unbanned), however, there was a final service commemoration in the church. Again it ended in pandemonium as the police attacked the attendees inside the church by throwing tear gas at them and by beating them with sjamboks.

From 1995 to 1998, the then Archbishop Desmond Tutu presided over several meetings of the TRC hearings held at Regina Mundi (Garson 2004). From 1995 onward the church started to raise funds to restore the damage done by the police. Regina Mundi eventually collected R1.5 million and made the necessary restorations.

At a ceremony marking the restoration of the church in 1997, President Nelson Mandela stated:

Regina Mundi served the greater Soweto community in times of need. It opened its doors to anti-apartheid activities when all other avenues were closed to the majority of oppressed ... It was this stance that earned Regina Mundi a reputation as one of Gauteng's greatest protest centres, a literal battlefield between forces of democracy and those who did not hesitate to violate a place of religion with teargas, dogs and guns. Regina Mundi became a world-wide symbol of the determination of our people to free themselves. (Garson 2004)

He further referred to Regina Mundi as a church that 'refused to allow God's Name to be used to justify discrimination and repression' (ANC 1997). These, amongst others, motivated Dr Mandela on 30 November 1997 to establish 30 November as 'Regina Mundi Day' in honour of the church.

In March 1998, Bill and Hilary Clinton, the then Presidential couple of the USA, visited this church and attended a service 'through a hard-hitting sermon on adultery at the height of the Monica Lewinsky scandal' (Harrison 2004:38) as Mohlomi Makobane, the parish priest, read from John 8:1-11. What made their visit so controversial is that they were allowed to partake in the Holy Communion, despite not being Catholics. As Clinton is a Baptist and his wife a Methodist, this constituted a breach of the cardinal rules of the Catholic Church (Garson 2004).

On 16 June 2011, just one year before the 50th anniversary of the church, Michelle Obama, the First Lady of the USA, during a visit to South Africa, recalled that sad day in her keynote speech in Regina Mundi where she addressed the Young African Women Leaders Forum:

And as the Archbishop noted, that June day wasn't the first, or the last, time that this church stood in the crosscurrents of history. It was referred to as 'the parliament of Soweto'. When the congregation sang their hymns, activists would make plans, singing the locations and times of secret meetings. Church services, and even funerals, often became anti-Apartheid rallies. And as President Mandela once put it, 'Regina Mundi became a world-wide symbol of the determination of our people to free themselves'. (The White House 2011)

Inside the church, one finds an honorarium or plaque donated by AZAPO in 1995 as well as a painting of faces of distinguished African freedom fighters like Nelson Mandela, Steve Biko, Desmond Tutu and student leader, Tsietsi Mashinini. There is also a painting entitled "The Madonna and Child of Soweto', mostly referred to as 'The Black Madonna', depicting a Black virgin Mary holding her baby Jesus. This picture was created by Larry Scully in 1973, on commission of the newspaper, The Star, and formed part of a campaign to raise funds to educate black children in South Africa. After the campaign, Harry Oppenheimer (who also bought the land on which the church was built) bought the painting and donated it to the church (Ndlovu et al. 2012:79). Hlangani (2012) reflected on the painting: 'A highly symbolic element of the painting is a large eye right under the Black Madonna'. Ndlovu et al. (2012) elaborated on the symbolic significance of the eye:

In a dramatic description of the aura of the painting, The Madonna and Child of Soweto hover over the grim urban landscape of Soweto. God the Father is the presenter - His hand - as in Byzantine art, symbolically suffices. Realism and abstraction interplay, just as does present suffering with future hope. The Holy Figures representing ... faith, hope and love become reality; while the temporary agony below becomes an 
abstraction within the overall design. The zig-zag motif of African Art suggests the endless rows of identical concrete houses; which in turn become the decorative design on the clothes of the Mother and Child - culminating in the V-sign formed by the Child's right hand representing ultimate triumph over evil. In His left hand He holds the black cross which links with the white cross [at the church - my addition] at the heart of Soweto. The landscape becomes a symbolic eye, a crucible and a catalyst for eventual good. (p. 90)

The stained glass windows of the church are decorated with scenes of Mary's life. These decorated windows were donated by Poland in 1998 (Hlangani 2012). Outside, in front of the church is an impressive park, with a fountain, benches and green lawns that were built by the City of Johannesburg. Memorial stones, including a 'peace pole' that was donated by Japanese Christians, and a plaque documenting the history of this church are also to be seen outside the church. An art gallery featuring photographic and art works can be found upstairs, documenting the history of the church (Garson 2004).

On 27 August 2012, the Sowetan reported that Regina Mundi has had its 50th celebrations. At the celebrations the Gauteng Premier, Nomvula Mokonyane, said: 'The important role of the church is that it helped to develop political consciousness. We must thank the church for instilling political consciousness' (Xaba 2012). Archbishop Buti Tlhagale also told the attendees how political activity of the time challenged the priests, especially in Regina Mundi, to participate in the struggle for freedom.

Currently this church continues to play an important role in the social life of Soweto, as weddings, funerals and baptisms are taking place here on a regular basis. The church is obviously also a prominent tourist attraction in Soweto.

\section{Conclusion}

The ANC had its main centenary celebrations in Mangaung on 08 January 2012. This depicted a milestone for a liberation movement that fought to the bitter end to regain freedom for everybody in South Africa. In 2014, the Government of South Africa celebrated two decades of democracy in South Africa. This was another milestone reached and was topped by a general election held in the country on 07 May 2014.

As the liberation struggle started as a non-violent movement towards freedom for all, the first five decades of the struggle, up to 1961, evidenced the fact that non-violence would not result in the apartheid regime being toppled. Especially after 1961, when apartheid took on a new momentum under the ruling National Party, the banned liberation movement or movements had to resort on better means to make their voice heard - acts of violence. This led to the death of many people on both sides of the political spectrum and eventually to the realisation that South Africa would only reach peace and political stability when the struggle was ended. This only happened in 1990 when the liberation parties were unbanned and ended in 1994 when the first democratic elections took place in South Africa.

During the years of active struggle in the country, especially during the 20th century, mainstream churches supported the struggle for freedom in specific (mostly passive) ways, but the Regina Mundi Church became a place where political meetings were held and where people took refuge from the police for different reasons. No church was as daring as Regina Mundi, which earned that church a date on the calendar, namely Regina Mundi Day on 30 November.

\section{Acknowledgements Competing interests}

The authors declare that they have no financial or personal relationships which may have inappropriately influenced them in writing this article.

\section{Authors' contributions}

W.O. and E.O. worked together on this article. W.O. was the project leader. Both authors contributed equally to this article.

\section{References}

ANC (African National Congress), 1987, 'Statement by Oliver Tambo at the World Council of Churches - Liberation movement dialogue', 5 May 1987, viewed 4 March 2016, from http://www.anc.org.za/show. php?id=4526

ANC (African National Congress), 1992, 'Nelson Mandela's speech to the Free Ethiopian Church of Southern Africa', 14 December 1992, Potchefstroom, viewed 4 March 2016, from http://www.anc.org.za/show. php?id=4161

ANC (African National Congress), 1997, 'Speech by President Nelson Mandela on the occasion of Regina Mundi Day', 30 November 1997, viewed 8 March 2016, from http://www.anc.org.za/show.php?id=3249/

ANC (African National Congress), 2011, 'A brief history of the African National Congress', viewed 7 March 2016, from http://www.anc.org.za/show.php?id=206

ANC Archives, s.a., viewed 12 March 2014, from http://ancarchives.org.za/view/ collections/alliances/

Boddy-Evans, A., 2001, '16 June 1976 student uprising in Soweto. Parts 1 and 2', viewed 17 March 2016, from http://africanhistory.about.com/od/apartheid/a/ Soweto-Uprising-Pt1.htm; http://africanhistory.about.com/od/apartheid/a/ Soweto-Uprising-Pt2.htm

Davie, L., 2006, '16 June 1976: "This is our day"', SouthAfrica.info, 15 June 2006, viewed 5 March 2016, from http://www.southafrica.info/about/history/ soweto-150606.htm\#.U1osmPmSySp

Garson, P., 2004, 'Regina Mundi - Queen of Soweto', 19 January 2004, viewed 7 March 2016, from http://www.southafrica.info/travel/cultural/reginamundi.htm\#.UOyEvmSySo

Harrison, P., 2004, South Africa's top sites: Struggle, 4th edn., Spearhead, Kenilworth, IL.

Hlangani, S., 2012, 'Regina Mundi Church celebrates 50th anniversary', 27 August 2012, viewed 8 March 2016, from http://www.thenewage.co.za/mobi/Detail. aspx? News ID $=60301 \&$ Cat ID $=1009$

Hlongwane, K.A., 2008, 'Commemoration, memory and monuments in the contested language of black liberation: The South African experience', The Journal of Pan African Studies 2(4), 135-170.

Hlongwane, K.A., Ndlovu, S.M. \& Mutloatse, M., 2006, Soweto '76: Reflections on the Liberation Struggles Commemorating the 30th Anniversary of June 16, 1976, Pan Macmillan and the Mutloatse Heritage Trust, Johannesburg.

Keung, N., 2014, 'Mysterious man in Canadian jail is Mbuyisa Makhubu, says brother of anti-apartheid icon', Thestar.com, viewed 14 March 2016, from http://www. thestar.com/news/immigration/2014/07/11/mysterious_man_in_canadian_jail_ is_mbuyisa_makhubu_says_brother_of_antiapartheid_icon.html

Komane, S., 2013, 'Govt awaits DNA results on Mbuyisa Makhubo', SABC News, viewed 14 March 2016, from http://www.sabc.co.za/news/a/9df67b8 0412 aac419ceabc9aacc0ad31/Govt-awaits-DNA-results-on-MbuyisaMakhubo

Mashabela, H., 2006, A people on the boil: Reflections of June 16, 1976 and beyond, 30th Anniversary edn., Jacana Media, Johannesburg.

Mbali, Z., 1987, The churches and racism: A black South African perspective, SCM Press, London.

Ndlovu, S.M., 1998, The Soweto uprisings: Counter-memories of June 1976, Ravan Press, Johannesburg. 
Ndlovu, S.M., 2006, 'Soweto part 1', in UNISA (ed.), The road to democracy in South Africa, 2(1970-1980), pp. 317-350, UNISA Press, Pretoria.

Ndlovu, S.M., Moloi, T., Theron-Bushell, B. \& Rossouw, S. (eds.), 2012, Regina Mundi Catholic Church: 1962-2012, Shereno Printers, Johannesburg.

Ndou, C., 2014, 'Iconic image "cost me my career"', The Citizen 17 June, 2014, 2.

Rakolote, S., 2013, 'Communist University: Joined at the hip: The church and the African National Congress' viewed 3 March 2016, from https://groups.google. com/forum/\#!topic/communist-university/jlhxkk88T14

SAHO (South African History Online), s.a., 'Pixley ka Isaka Seme', viewed 7 March 2016, from http://www.sahistory.org.za/ people/pixley-ka-isaka-seme

Simbao, R.K., 2007, 'The thirtieth anniversary of the Soweto uprisings: Reading the shadow in Sam Nzima's iconic photograph of Hector Pieterson', African Arts 40(2), 52-69. http://dx.doi.org/10.1162/afar.2007.40.2.52

South African Press Association, 1997, 'Churches confess to failures under apartheid', viewed 2 March 2016, from http://www.justice.gov.za/trc/media\%5C1997\% 5C9711/s971117k.htm

Switzer, L. (ed.), 1997, South Africa's alternative press: Voices of protest and resistance 1880-1960, Cambridge University Press, Cambridge.
The Associated Press, 1960, 'South Africa bans African National Congress', 8 April 1960, viewed 1 March 2016, form http://www.aaregistry.org/historic events/ view/south-africa-bans-african-national-congress

The History of the SACP, 1912-1990, s.a., viewed 17 April 2014, from http://www. sacp.org.za/docs/history/sacp1912-1990.html

The Kairos Document, 1995, Challenge to the church: A theological comment on the political crisis in South Africa, viewed 25 April 2014, from http://www.sahistory org.za/pages/library-resources/official\%20docs/kairos-document.htm

Thema, S., 1953, 'How Congress began', viewed 1 April 2014, from http://www.anc. org.za/show. . php?id=4343

The White House, 2011, 'Remarks by the first lady during keynote address at Young African Women Leaders Forum', viewed 2 April 2014, from http://www. whitehouse.gov/the-press-office/2011/06/22/remarks-first-lady-during-keynoteaddress-young-african-women-leaders-fo

Wilkins, I. \& Strydom, H., 2012, The Super-Afrikaners: Inside the Afrikaner Broederbond, Jonathan Ball Publishers, Jeppetown.

Xaba, V., 2012, 'Regina Mundi history preserved', Sowetan online, 27 August 2012 viewed 31 March 2014, from http://www.sowetanlive.co.za/news/2012/08/27/ regina-mundi-history-preserved 